\title{
A profile of sexually active male adolescent high school students in Lima, Peru
}

\author{
Perfil de los adolescentes varones sexualmente \\ activos en colegios secundarios de Lima, Peru
}

Jesús L. Chirinos 1,2

Victor C. Salazar 1

Claire D. Brindis 2

\footnotetext{
1 Instituto de Estudios de Población, Universidad Peruana Cayetano Heredia. Av. Honorio Del gado 430, San Martín de Porras, Lima 31, Peru.

2 Center for Reproductive Health Policy Research

Institute for Health Policy Studies, School of Medicine, University of California. 3333 California St., Room 265, San Francisco, CA 94143-0936, U.S.A. brindis@itsa.ucsf.edu
}

\begin{abstract}
To document knowledge and atti tudes regarding sexuality and sexual practices of male adolescent high school students in Lima, Peru, a self-administered, anonymous survey was completed by 991 male adol escents aged 12-19 as part of a School-Based Sex Education Intervention model. Questions concerned sociodemographic information; family characteristics; personal activities; knowledge and attitudes regarding sexuality; sexual experience; and contraceptive use. Knowledge related to sexuality was limited. Males tended to mainly discuss sexuality with their male peers (49.8\%). Attitudes towards sexual activity and condom use were largely positive, although some mal es expressed ambivalent feel ings towards the latter. Of the sample, $43 \%$ had ever had sex; age at first sexual intercourse was 13 years. While $88 \%$ of the samplewould use condoms, $74 \%$ also gave reasons for not using them. Sexual activity was rel ated to age, ever having repeated a grade, living with only one parent or in a mixed family, activities such as going to parties, use of alcohol, tobacco, and drugs, and viewing pornographic videos or magazines. Many male adolescents were at risk of causing an unintended pregnancy or acquiring an STD.

Key words Adolescent; Sex Behavior; Contraception
\end{abstract}

Resumen Con el objetivo de documentar el nivel de conocimiento y las actitudes con respecto a sexuali dad y las prácti cas sexuales de los adolescentes varones de col egi os secundari os en Lima, Peru, 991 estudiantes varones, entre los 12-19 años, completaron una encuesta autoaplicable y anónima dentro de un Programa de Prevención de Comportamientos Sexual es de Riesgo. Datos de la encuesta: soci odemográficos de la familia; de actividades personales; de conocimiento y actitudes con respecto a la sexualidad; de experiencia sexual y uso de anticonceptivos. El conocimi ento sobre sexualidad es limitado. Los varones discuten principalmentesobre sexualidad con sus pares varones $(49,8 \%)$. Las actitudes hacia la actividad sexual y el uso de condones fueron positivas, pero algunos expresaron sentimientos ambivalentes en cuanto a su uso. El 43\% había tenido relaciones coital es al guna vez y la edad promedio del inicio sexual fue de 13 años. Mientras que el $88 \%$ de la muestra usaría condones, el $74 \%$ también dio razones para no usarlos. La actividad sexual se asoció a la edad, a haber repetido un grado, a vivir con uno delos padres o con una familia re estructurada, con actividades como ir a fiestas, uso de alcohol, tabaco y drogas, y ver revistas o vi deos pornográficos. Muchos de los adolescentes varones estuvieron en riesgo de ocasionar un embarazo no planeado o adquirir una ETS.

Palabras clave Adolescente, Comportamiento Sexual, Anticoncepción 


\section{Introduction}

Sexuality-related problems, such as sexually transmitted diseases (STDs), including Acquired Immunodeficiency Syndrome (AIDS), and unintended pregnancies (UIPs) are issues of worldwide concern (CDC, 1992) and particularly in developing countries such as those of South America and the Caribbean. A number of population-based surveys document that adolescents initiate sexual relations at an early age without adequate use of contraception (Morris, 1988; ENJOVEN, 1992; ENDES, 1997). In Latin America, adolescents' level of knowledge about AIDS is high (80\%-90\%); however, many adolescents continue to feel that they are not personally vulnerable when they have sexual relations (CDC, 1992; Morris, 1994). The spontaneous nature of their initial sexual experience is reflected in the finding that one of the most important reasons for not using contraceptives is because they did not expect to engage in sex (ENJOVEN, 1992). Similar findings are documented in American adolescents with a co-occurrence of other health risk behaviors, such as drug and alcohol use (Weisman, 1989; Resnick et al., 1997; Brener \& Collins, 1998).

In Peru, adolescents are also at risk of experiencing the negative consequences of their unprotected sexual relations (Loli et al., 1987; Wulf \& Singh, 1991; ENDES, 1992). An important knowledge gap exists in Latin America as a result of the lack of systematic information about the participation and roles of adolescent males in sexual and contraceptive decisionmaking. This information is necessary in order to achieve a reduction in the high incidence of STDs and UIPs in both Latin America and the United States (Dryfoos, 1988; Edwards, 1994; Moore \& Driscoll, 1997). Thus, while there are no data available about UIPs fathered by male adolescents and STDs, among female adolescents ages $15-19$ (representing $21 \%$ of all reproductive-age women in Peru), the fertility rate is $55 / 1,000$ women in urban areas and 139/1,000 in rural areas. Although birth rates are high, $97 \%$ of reproductive-age women know or have heard about at least one contraceptive method. However, there exists a substantial gap between knowledge and contraceptive use. For example, only $31 \%$ of sexually active adolescents have used a modern contraceptive method. The majority of adolescent women (53\%) also expressed that they wanted to have a child in the next two years or beyond this period (ENDES, 1997), thus perhaps decreasing the likelihood of seeking contraceptive protection. In addition, social stigma related to adolescent sexual activity is often associated with contraceptives, resulting in additional barriers in seeking sexual and reproductive health care, since many adolescents hope to deny their sexual activity precisely by avoiding the contraceptive method which symbolizes their behavior (Aral, 1992; Brunham \& Embree, 1992; Lande, 1993).

The purpose of this study was to document the level of knowledge and attitudes regarding sexuality and sexual practices among male adolescent students attending the third and fourth secondary school grades (equivalent to ninth and tenth grades in United States) in four high schools in Lima, Peru.

\section{Research design and methods}

An anonymous, self-administered survey was completed by students ages 12-19. The survey took approximately one hour to complete and required the signed consent of their parents and school administrators. From a pool of $12 \mathrm{el}-$ igible schools in an urban school district, four of these were randomly selected because they met overall criteria for participation, including similar mixture of low-income students, school size, and similar numbers of students who had been referred for health services by school administrators.

The adolescent male questionnaire was comprised of a 50-item instrument concerning six areas: 1) sociodemographic information; 2 ) family characteristics; 3) personal activities; 4) knowledge and attitudes regarding sexuality; 5) sexual experience; and 6) contraceptive use. The data were gathered as a part of a larger project to develop an intervention model entitled "Prevention of Sexual Risk Behaviors: A SchoolBased Sex Education Intervention" which was implemented by the Instituto de Estudios de Población dela Universi dad Peruana Cayetano Heredia from April 1995 to December 1996, funded by the Ford Foundation. The study variables were:

- Sociodemographic information: age, grade, repeated grade, religion.

- Family characteristics: number of persons living at home, type of persons living at home, parents' marital status, parents' schooling, parents' occupations.

- Personal activities and frequency: sports, seeing friends, going to parties, seeing relatives, viewing pornographic videos or magazines, and alcohol, tobacco, and drug use.

- Sexuality

a) Information: with whom they talk about sexuality. 
b) Knowledge: self-rating of level of knowledge.

c) Attitudes: preventing AIDS by use of protection when having sex; a child would be an obstacle to continuing studies; would be impossible to say no to having sex; can control sexual desire; it is difficult to become accustomed to using a condom.

d) Hypothetical situations: it is possible to: acquire an STD; become infected by HIV; get someone pregnant.

e) Couple relationships and sexual experience: having had a girlfriend; number of girlfriends; sexual attraction for and contact with males, females, or both; reasons for having sex; age at first ejaculation; age at first sexual intercourse; how long since last sexual intercourse.

f) Use of contraceptives and pregnancy experience: willingness to: use condoms; attend family planning center; have anal sex; reasons for not using a condom; perception of peers who have had sex; perception of peers who have used contraception. Used contraception in first sexual intercourse; type of contraceptive used. Last sexual intercourse: type of contraceptive. Ever gotten someone pregnant; fathered a child.

Age categories were defined statistically in order to weigh the cells, with early adolescence defined as 12 to 14 , middle as 15 , and late adolescence as 16 to 19 years old. These breakdowns reflect the age groups participating in this study and the pool of participants. Sexually active was defined by whether the teen had ever had sex. A logistic regression analysis was performed with sexually active as the dependent variable in order to create a profile of sexually active male adolescents. The independent variables were those with a significant OR equal to or larger than 1.5 in the bivariate analysis. These variables were fitted in a logistic regression model in order to identify the variables most predictive of sexually active males.

\section{Results}

A total of 1,020 surveys were administered in the selected schools, with 991 (97\%) of the sample available for analysis. The remainder were eliminated because surveys were incomplete.

\section{Sociodemographic information}

Mean age of participants was $14.9 \pm 1.15$ ( $\mathrm{n}=991$, range $12-19$ and median $=15$ ). Of the sample, $53.9 \%$ ( $n=521 / 966$ ) was in the third grade and $46.1 \%(n=445)$ in the fourth; 38.4\% ( $n=372 / 969)$ had ever repeated a grade. The majority of students were Catholic: $87.4 \%(n=850 / 973)$.

\section{Family characteristics}

The mean number of persons who lived in the household was $8 \pm 5.4$, with a median of seven ( $n=885$, range 1-28). The majority of students, $74.7 \%$ ( $n=731 / 979)$, lived with both parents, with or without siblings, and with or without other relatives; $80.8 \%$ ( $n=788 / 975)$ of their parents were married or lived together. As for educational level of parents, 58.3\% $(n=561 / 962)$ of mothers and $69.4 \%$ ( $n=648 / 934)$ of fathers had completed high school. The majority of mothers, $71 \%$ ( $n=572 / 804)$, worked in the home. Almost half of fathers (49\%) were either employed, merchants, or professionals; $47 \%(n=332 / 706)$ were either farmers, factory workers, or had other occupations, such as carpenters or bricklayers; only $4 \%(n=28)$ were unemployed or retired.

\section{Personal activities}

Favorite activities, i.e., those that the adolescents most frequently engaged in were: sports (35.5\%, $\mathrm{n}=339 / 954)$, seeing friends ( $15.2 \%, \mathrm{n}=145)$, going to parties ( $14.7 \%, n=140$ ), seeing relatives (13\%, $n=124)$, and other activities (i.e. playing video games; hel ping at home; using tobacco, alcohol, and drugs; and viewing pornographic videos or magazines) accounted for the remaining percent $(21.6 \%)$.

The following activities were performed "daily to once a week": "watching pornographic videos or reading pornographic magazines" (34.8\%, n =294/844), "drinking alcohol" (28.8\%, $\mathrm{n}=241 / 836)$, "smoking cigarettes" (21.2\%, n = $174 / 820)$, and "using drugs" (6.3\%, $n=52 / 822)$. However, it is important to note that larger proportions of students indicated that they participated in these activities approximately once a month (37.9\% "watching pornographic videos or reading pornographic magazines", 34.6\% "drinking alcohol", 37.3\% "smoking cigarettes", and $42.7 \%$ "using drugs").

Knowledge and attitudes

regarding sexuality

When students were asked "With whom do you discuss topics related to sexuality?", they most often indicated that they talked with a male friend (49.8\%, $n=493 / 990)$, with their fathers (20.8\%, $n=206 / 990)$, with their mothers (13.9\%, $\mathrm{n}=138)$, with no one $(12.8 \%, \mathrm{n}=126 / 988)$, and with their teachers $(5.9 \%, n=58 / 989)$. 
When asked to rate their level of knowledge regarding sexuality and contraceptives, 79\% stated that they had either an average or high degree of knowledge $(63.4 \%, n=621 / 980$, and $15.6 \%, n=153$, respectively); $21 \%$ stated that they knew "little" or "nothing" in their self-ratings of knowledge $(19.9 \%, \mathrm{n}=195$ and $1.1 \%, \mathrm{n}=$ 11 respectively). However, their perceptions regarding their level of knowledge were inconsistent with the factual findings as measured by their correct answers to 20 basic questions. Results showed that $66.9 \%$ of the sample provided ten or more correct answers, with a mean score of $10.6 \pm 3.3$ ( $n=985$, range $0-18$ and median of 11).

A majority of respondents, $77.3 \%$ ( $n=731$ / 946), expressed an interest in "learning how to prevent AIDS", while 88.7\% ( $n=840 / 947)$ indicated that they "would protect themselves when they have sexual relationships". In part, the latter response reflects the fact that $64.1 \%(n=$ $609 / 950$ ) indicated that "a child at this moment would be an obstacle to completing their studies". Of the group, 58.4\% ( $n=550 / 942$ ) answered that if faced with the opportunity to have sex, "they could decline having sexual relationships", while $70.6 \%$ ( $n=676 / 958$ ) expressed that "they can control their sexual desires". Almost a third of students (29.2\%, $n=276 / 945)$ expressed that if they were to have sex "it would be difficult to use a condom", while another third (30.5\%, $\mathrm{n}=288$ ) indicated that they did not know what they would do.

In a series of hypothetical situations providing students with an opportunity to indicate their risk perceptions regarding "whether it is possible" to acquire a STD, to be infected with HIV, and to get someone pregnant, the majority of students indicated that they did not know if they were vulnerable or indicated that they were not at risk of STDs (34\%, $n=323 / 946)$, HIV (61.8\%, $n=584 / 945)$, or pregnancy $(55.5 \%, n=$ 530/954). However, sexually active adolescent boys were more likely to indicate their self-perceived risk of acquiring an STD and getting a girl pregnant.

\section{Sexual experience}

The majority of respondents had had a girlfriend $(73.5 \%, \mathrm{n}=706 / 961)$ and the mean number of relationships was $3.8 \pm 3.6$ ( $n=580$, range 1-21 and median of 3). Most respondents indicated that they were attracted to the opposite sex ( $88.6 \%, n=851 / 960)$, while $5.7 \%$ disclosed that they were attracted to males or to both males and females. The majority of students reported that they had had a heterosexu- al contact $(57.8 \%, n=544 / 941)$ and $6.5 \%$ reported that they had had a sexual contact with a male or with both males and females.

Nearly three-fourths of the sample $(70.1 \%$, $n=650 / 927)$ had had their first ejaculation, with the mean age of $13.3 \pm 1.36(n=606$, range 8-17 and median of 13). Less than half of the sample indicated that they had initiated having $\operatorname{sex}(42.6 \%, n=401 / 942)$, with the mean age of $13.2 \pm 1.9(n=364$, range $5-19$ and median of 14$)$.

First coitus had been with a female friend, girlfriend, or relative in $82.2 \%$ ( $n=327 / 398)$ of the cases, while $17.8 \%$ had been with a casual acquaintance or prostitute. Although many of the adolescent males had initiated sexual relations, 39.5\% ( $n=162 / 410$ ) had had their last act of sexual intercourse during the previous year, and the pattern of partner choice appeared to be consistent across time, i.e., girlfriend, female friend, or relative in $82.4 \%$ of cases $(n=324 / 393$ ) and the remainder $(17.6 \%, n=69)$ with a casual acquaintance or prostitute.

Students were able indicate their reasons for being involved in a sexual relationship; $68.4 \%$ ( $n=611 / 894)$ indicated that their "fear of losing their partner, to get closer to their partner, if their partner had asked to have sex, for love, if both of them decided to have sex, or both of them are prepared" as the principal reasons for being in a sexual relationship. The remaining $31.6 \%$ of students mentioned "for pleasure, because it is fun, because of peer pressure, in order to know how it feels, because men do it, or to satisfy bodily needs" as their motivation to be in a sexual relationship.

\section{Contraceptive use}

Facing the possibility of having sexual relationships, $87.7 \%$ ( $n=822 / 937)$ indicated that they would use a condom and $80 \%$ ( $n=722 / 902$ ) would seek information from a family planning center. Perhaps reflecting a concern regarding pregnancy, a large proportion of students indicated that they would have "anal sex" (32.5\%, $n=279 / 859)$ or that they did not know what they would do $(27.2 \%, n=234)$. Although students expressed that they would likely use a condom, a clear majority of them $(73.6 \%, n=$ $644 / 875$ ) provided a number of reasons why they would not use protection: expense, reduction in pleasure, condoms were seen as being used only by adults, as ineffective, or dangerous to their health. The remainder $(26.4 \%)$ indicated that they would use a condom.

Perceptions regarding peers' experience with sex was also documented: nearly half of the sample $(42.5 \%, n=412 / 970)$ perceived that 
many of their male peers had already had sex. Only a low proportion of the sample $(19 \%, n=$ $185 / 974)$ perceived that many of their peers use condoms.

Contraceptives had been used in the first coitus by $32.1 \%$ ( $n=126 / 392$ ) of the sexually active males, increasing to $37.5 \%$ ( $n=156 / 416$ ) during their most recent sexual intercourse. Condoms were the most common birth control method used: $78 \%$ ( $n=85 / 109)$ of students stated that they had used a condom in their first sexual experience and $84.1 \%(n=106 / 126)$ in the most recent sexual intercourse.

A small number of students reported that they had ever gotten a girl pregnant $(7.7 \%, \mathrm{n}=$ $31 / 401)$; of this number, $27.8 \%(n=5 / 18)$ had fathered a child, 13 girls had miscarried, and there was no information available on the remaining 13 sexual partners.

\section{Bivariate and multivariate analysis}

All variables were crossed with age groups in order to observe if there were any differences by age. The results show differences as age increases (Table 2). A larger number of girlfriends at earlier ages, younger age at first ejaculation, and younger age at first coitus were found to be associated with age.

"Sexually active" was analyzed as a dependent variable, and statistically significant differences were noted among those who were sexually active and those who were not. As shown in
Tables 3 and 4, those who had repeated a grade, lived with one parent only, smoked tobacco, drank alcohol, or used drugs frequently, and/or had more girlfriends were more likely to be sexually active. Logistic regression results identified the following variables as the best predictors of sexually active males: repeated a grade, spoke with their girlfriends regarding sex, had first ejaculation at an early age, and currently had a girlfriend (Table 5).

\section{Discussion}

Results from this study document a number of biological, social, and contextual factors which appear to be associated with sexual activity among Latino males living in Peru. Study results clearly show a relationship between a male's age, social and sexual maturation, and level of sexual and contraceptive knowledge. Sexual activity was also found to be significantly associated with a variety of activities including use of tobacco, alcohol, and drugs, having had a girlfriend and overall number of girlfriends, age at first ejaculation, and peers who were sexually active. The association between sexual activity and high incidence of failure in school, as reflected in the number of boys who had repeated a school grade, is consistent with other studies of adolescent risk-taking behaviors (Upchurch \& McCarthy, 1990; Resnick et al., 1997).

Table 1

Number of girlfriends, age at first ejaculation, and age at sexual debut by age.

\begin{tabular}{|c|c|c|c|c|c|c|c|}
\hline Variable & $\mathrm{n}$ & $\%$ & Mean & Median & SD & Range & $\mathrm{p}$ \\
\hline Number of girlfriends & 580 & 59 & 3.84 & 03 & 3.63 & $(01-21)$ & $0.0000 *$ \\
\hline$\leq 14$ & 221 & & 3.22 & 02 & 2.84 & $(01-15)$ & \\
\hline 15 & 186 & & 3.60 & 02 & 3.37 & $(01-20)$ & \\
\hline$\geq 16$ & 173 & & 4.90 & 03 & 4.50 & $(01-21)$ & \\
\hline Age at 1 st ejaculation & 106 & 61 & 13.29 & 13 & 1.36 & $(08-18)$ & $0.0000 *$ \\
\hline$\leq 14$ & 190 & & 12.76 & 13 & 1.05 & $(09-17)$ & \\
\hline 15 & 215 & & 13.21 & 13 & 1.24 & $(08-16)$ & \\
\hline$\geq 16$ & 201 & & 13.89 & 13 & 1.50 & $(08-17)$ & \\
\hline Age at sexual debut & 364 & 37 & 13.24 & 14 & 1.96 & $(05-19)$ & $0.0000 *$ \\
\hline$\leq 14$ & 93 & & 12.33 & 13 & 1.64 & $(05-16)$ & \\
\hline 15 & 122 & & 13.13 & 14 & 1.79 & $(07-15)$ & \\
\hline$\geq 16$ & 149 & & 13.89 & 14 & 2.05 & $(07-19)$ & \\
\hline
\end{tabular}

$\mathrm{n}=$ number, $(\%)=$ percent, $\mathrm{SD}=$ standard deviation.

$\mathrm{K}-\mathrm{W}$ means comparison. $*$ significant. 
Table 2

Sociodemographic information, family characteristics, and personal activities by age.

\begin{tabular}{|c|c|c|c|c|c|c|c|c|}
\hline \multirow[t]{2}{*}{ Variables } & \multicolumn{2}{|c|}{$\leq 14$} & \multicolumn{2}{|c|}{15} & \multicolumn{2}{|c|}{$\geq 16$} & \multicolumn{2}{|c|}{ Total } \\
\hline & $\mathrm{n}$ & $\%$ & $n$ & $\%$ & $\mathrm{n}$ & $\%$ & $\mathrm{n}$ & $\mathrm{p}$ \\
\hline \multicolumn{9}{|l|}{ Sociodemographic Information } \\
\hline Age & 394 & 39.8 & 327 & 33 & 270 & 27.2 & 991 & \\
\hline Repeated a grade & 34 & 8.8 & 125 & 39.1 & 213 & 80.7 & 969 & $0.000 *$ \\
\hline \multicolumn{9}{|l|}{ Family Characteristics } \\
\hline Type of persons in home & & & & & & & 979 & $0.000 *$ \\
\hline Both parents and others & 313 & 80.3 & 248 & 76.3 & 170 & 64.4 & & \\
\hline Father or mother/others & 77 & 19.7 & 77 & 23.7 & 94 & 35.6 & & \\
\hline Marital status of parents & & & & & & & 975 & $0.0246 *$ \\
\hline Married or live together & 324 & 83.9 & 264 & 81.5 & 200 & 75.5 & & \\
\hline Other & 62 & 16.1 & 60 & 18.5 & 65 & 24.5 & & \\
\hline Educational level - mother & & & & & & & 962 & $0.0059 *$ \\
\hline Elementary/incomplete high school & 147 & 38.7 & 123 & 38.6 & 131 & 50.0 & & \\
\hline Completed high school & 234 & 61.4 & 196 & 61.4 & 131 & 50.0 & & \\
\hline Educational level - father & & & & & & & 934 & $0.0013^{*}$ \\
\hline Elementary/incomplete high school & 100 & 26.5 & 88 & 28.4 & 98 & 39.7 & & \\
\hline Completed high school & 277 & 73.5 & 222 & 71.6 & 149 & 60.3 & & \\
\hline Father's occupation & & & & & & & 706 & $0.0027 *$ \\
\hline Unemployed/worker/farmer & 137 & 55.1 & 121 & 48.5 & 102 & 38.6 & & \\
\hline Employed/merchant/professor & 168 & 44.9 & 114 & 51.5 & 64 & 61.4 & & \\
\hline \multicolumn{9}{|l|}{ Personal Activities } \\
\hline Favorite & & & & & & & 954 & $0.3956 *$ \\
\hline Sports & 143 & 37.5 & 112 & 35.8 & 84 & 32.3 & & \\
\hline Friends/going to parties & 91 & 23.9 & 107 & 34.2 & 87 & 33.5 & & \\
\hline \multicolumn{9}{|l|}{ Frequency of activities } \\
\hline Drink alcohol & & & & & & & 836 & $0.0000 *$ \\
\hline Daily - once a month & 179 & 53.0 & 185 & 67.5 & 174 & 74.1 & & \\
\hline Never & 159 & 47.0 & 89 & 32.5 & 58 & 25.9 & & \\
\hline View pornographic videos or magazines & & & & & & & 844 & $0.0004 *$ \\
\hline Daily - once a month & 229 & 66.2 & 215 & 76.2 & 170 & 78.7 & & \\
\hline Never & 117 & 33.8 & 67 & 23.8 & 46 & 21.3 & & \\
\hline Use tobacco & & & & & & & 820 & $0.0000^{*}$ \\
\hline Daily - once a month & 169 & 50.5 & 169 & 61.4 & 142 & 67.6 & & \\
\hline Never & 166 & 49.6 & 106 & 38.5 & 68 & 32.4 & & \\
\hline \multicolumn{9}{|l|}{ Knowledge } \\
\hline Self-rating & & & & & & & 980 & 0.7934 \\
\hline Average - great deal & 309 & 79.0 & 260 & 80.5 & 205 & 77.0 & & \\
\hline Little - nothing & 82 & 20.9 & 63 & 19.5 & 61 & 23.0 & & \\
\hline Actual level & & & & & & & 985 & 0.6545 \\
\hline$\geq 10$ correct answers & 259 & 66.1 & 216 & 66.1 & 184 & 69.2 & & \\
\hline$\leq 9$ & 133 & 33.9 & 111 & 33.9 & 82 & 30.8 & & \\
\hline
\end{tabular}


Table 2 (continued)

\begin{tabular}{|c|c|c|c|c|c|c|c|c|}
\hline \multirow[t]{2}{*}{ Variables } & \multicolumn{2}{|c|}{$\leq 14$} & \multicolumn{2}{|c|}{15} & \multicolumn{2}{|c|}{$\geq 16$} & \multicolumn{2}{|c|}{ Total } \\
\hline & $\mathrm{n}$ & $\%$ & $\mathrm{n}$ & $\%$ & $\mathrm{n}$ & $\%$ & $\mathrm{n}$ & $\mathrm{p}$ \\
\hline \multicolumn{9}{|l|}{ Attitudes } \\
\hline $\begin{array}{l}\text { A child would be an obstacle } \\
\text { to continuing studies }\end{array}$ & & & & & & & 950 & $0.0020 *$ \\
\hline Yes & 272 & 70.6 & 189 & 59.4 & 148 & 59.9 & & \\
\hline No & 81 & 21.0 & 83 & 26.1 & 76 & 30.8 & & \\
\hline Don't know & 32 & 8.3 & 46 & 14.5 & 23 & 9.3 & & \\
\hline \multicolumn{9}{|l|}{ Hypothetical situations } \\
\hline Acquire an STD & & & & & & & 946 & $0.0380 *$ \\
\hline Yes & 136 & 35.9 & 131 & 40.8 & 116 & 47.2 & & \\
\hline No & 142 & 37.5 & 114 & 35.5 & 67 & 27.2 & & \\
\hline Don't know & 101 & 26.6 & 76 & 23.7 & 63 & 25.6 & & \\
\hline \multicolumn{9}{|c|}{ Partner relationships and sexual experience } \\
\hline Ever had girlfriend & 248 & 64.6 & 237 & 74.3 & 221 & 85.7 & 961 & $0.0000 *$ \\
\hline Sexual contact & & & & & & & 941 & $0.0036 *$ \\
\hline Male & 5 & 1.3 & 7 & 2.2 & 4 & 1.6 & & \\
\hline Female & 189 & 50.7 & 186 & 59.0 & 169 & 66.8 & & \\
\hline Male and female & 18 & 4.8 & 15 & 4.8 & 12 & 4.7 & & \\
\hline None & 161 & 43.2 & 107 & 34 & 68 & 26.9 & & \\
\hline Ever had sex & 110 & 29.5 & 134 & 43.2 & 157 & 60.6 & 401 & $0.0000 *$ \\
\hline \multicolumn{9}{|l|}{ Pregnancy and contraception } \\
\hline Ever gotten someone pregnant & 6 & 5.4 & 5 & 3.7 & 20 & 12.7 & 401 & $0.0845^{*}$ \\
\hline Woman should protect herself & & & & & & & 860 & $0.0013^{*}$ \\
\hline Yes & 60 & 17.4 & 53 & 18.5 & 70 & 30.6 & & \\
\hline No & 212 & 61.4 & 182 & 63.6 & 126 & 55.0 & & \\
\hline Don't know & 73 & 21.2 & 51 & 17.8 & 33 & 14.4 & & \\
\hline Know peers who have sex & & & & & & & 970 & $0.0000 *$ \\
\hline A lot & 126 & 32.8 & 147 & 45.4 & 139 & 53.1 & & \\
\hline Few - no one & 135 & 35.1 & 99 & 30.6 & 79 & 30.2 & & \\
\hline Don't know & 123 & 32.0 & 78 & 24.1 & 44 & 16.8 & & \\
\hline Know peers who use contraception & & & & & & & 974 & $0.0000 *$ \\
\hline A lot & 60 & 15.6 & 56 & 17.2 & 69 & 26.2 & & \\
\hline Few - no one & 177 & 45.9 & 178 & 54.6 & 145 & 55.1 & & \\
\hline Don't know & 148 & 38.4 & 92 & 28.2 & 49 & 18.6 & & \\
\hline
\end{tabular}

* significant. $p$ value for $\chi^{2}$

Family structure was also seen to bear a relationship to sexual activity. One-fourth of the sample lived in either a single-parent or mixed family; this group was more likely to be sexually active as compared to students living with two parents. Similar patterns have been noted in other research, which predicts earlier sexual debut with non-traditional family structures (McCarthy \& Menken, 1989; Kieman \& Hobcraft, 1997). Many of the participants were also being raised in low socioeconomic family environments, which were further strained by the pres- sure to support extended family members. These factors may have contributed to the limited contact between parents and their children and fewer opportunities to discuss sex information. It may also reflect parents' ambivalence towards parental messages provided to males in cultures where social norms may support a man's early sexual experience. These findings are somewhat consistent with studies demonstrating that an adequate family context, defined as the presence of both parents and a sense of connectedness within the fami- 
Table 3

Profile of sexually active and non-sexually active male students

\begin{tabular}{|c|c|c|c|c|c|c|c|c|}
\hline \multirow[t]{2}{*}{ Variable } & \multicolumn{2}{|c|}{ SA } & \multicolumn{2}{|c|}{ NSA } & \multicolumn{2}{|c|}{ Total } & \multirow{2}{*}{$\begin{array}{l}\mathrm{RR} \\
(\mathrm{Cl})\end{array}$} & \multirow[t]{2}{*}{$\mathrm{p}$} \\
\hline & $\mathrm{n}$ & $\%$ & $n$ & $\%$ & $n$ & $\%$ & & \\
\hline Age & & & & & 942 & 100.0 & 1.47 & $0.0000 *$ \\
\hline$\leq 14$ & 110 & 29.5 & 263 & 70.5 & 373 & 39.6 & $(1.2-1.79)$ & \\
\hline 15 & 134 & 43.2 & 176 & 56.8 & 310 & 32.9 & 1.4 & $0.0000 *$ \\
\hline$\geq 16$ & 157 & 60.6 & 102 & 39.4 & 259 & 27.5 & $(1.19-1.65)$ & \\
\hline \multirow[t]{2}{*}{ Repeated grade } & & & & & 922 & & 1.65 & $0.0000 *$ \\
\hline & 203 & 56.9 & 154 & 43.1 & 357 & 38.7 & $(1.42-1.9)$ & \\
\hline \multirow{3}{*}{$\begin{array}{l}\text { Type of persons living at home } \\
\text { Father or mother or others }\end{array}$} & & & & & 931 & & 1.25 & $0.0000 *$ \\
\hline & & & & & & & $(1.07-1.47)$ & \\
\hline & 118 & 49.8 & 119 & 50.2 & 237 & 25.5 & & \\
\hline Both parents and others & 276 & 39.8 & 418 & 60.2 & 694 & 74.5 & & \\
\hline \multicolumn{9}{|l|}{ Personal activities } \\
\hline \multirow[t]{3}{*}{ Friends/going to parties } & & & & & 910 & & 1.19 & $0.0354 *$ \\
\hline & 130 & 47.4 & 144 & 52.6 & 274 & 30.1 & $(1.02-1.39)$ & \\
\hline & & & & & & & 0.81 & $0.0104 *$ \\
\hline Sports & 116 & 36.5 & 202 & 63.5 & 318 & 34.9 & $(0.68-0.96)$ & \\
\hline \multicolumn{9}{|l|}{ Frequency of activities } \\
\hline Go to parties & & & & & 862 & & 1.4 & $0.0165 *$ \\
\hline Daily - once a month & 339 & 44.4 & 425 & 55.6 & 764 & 88.6 & $(1.04-1.9)$ & \\
\hline Never & 31 & 31.6 & 67 & 68.4 & 98 & 11.4 & & \\
\hline Drink alcohol & & & & & 796 & & 1.63 & $0.0000 *$ \\
\hline Daily - once a month & 249 & 49.1 & 258 & 50.9 & 507 & 63.7 & $(1.34-1.99)$ & \\
\hline Never & 87 & 30.1 & 202 & 69.9 & 289 & 36.3 & & \\
\hline Use drugs & & & & & 784 & & 1.3 & $0.0020 *$ \\
\hline Daily - once a month & 181 & 47.3 & 202 & 52.7 & 383 & 48.9 & $(1.1-1.53)$ & \\
\hline Never & 146 & 36.4 & 255 & 63.6 & 401 & 51.1 & & \\
\hline View pornographic videos or magazines & & & & & 807 & & 1.83 & $0.0000 *$ \\
\hline Daily - once a month & 282 & 47.9 & 307 & 52.1 & 589 & 73.0 & $(1.44-2.32)$ & \\
\hline Never & 57 & 26.1 & 161 & 73.9 & 218 & 27.0 & & \\
\hline Help out at home & & & & & 857 & & 0.67 & $0.0088 *$ \\
\hline Daily - once a month & 328 & 40.3 & 486 & 59.7 & 814 & 95.0 & $(0.52-0.86)$ & \\
\hline Never & 26 & 60.5 & 17 & 39.5 & 43 & 5.0 & & \\
\hline Use tobacco & & & & & 782 & & 1.41 & $0.0001^{*}$ \\
\hline Daily - once a month & 213 & 46.5 & 245 & 53.5 & 458 & 58.6 & $(1.17-1.69)$ & \\
\hline Never & 107 & 33.0 & 217 & 67.0 & 324 & 41.4 & & \\
\hline
\end{tabular}


Table 3 (continued)

\begin{tabular}{|c|c|c|c|c|c|c|c|c|}
\hline \multirow{2}{*}{ Variable } & \multicolumn{2}{|c|}{ SA } & \multicolumn{2}{|c|}{ NSA } & \multicolumn{2}{|c|}{ Total } & \multirow{2}{*}{$\begin{array}{l}\text { RR } \\
\text { (CI) }\end{array}$} & \multirow[t]{2}{*}{$p$} \\
\hline & $\mathrm{n}$ & $\%$ & $n$ & $\%$ & $n$ & $\%$ & & \\
\hline \multicolumn{9}{|c|}{ Sexuality information } \\
\hline \multicolumn{9}{|c|}{ With whom talk about sex } \\
\hline \multirow[t]{2}{*}{ Mother } & & & & & 941 & & 0.78 & $0.0363 *$ \\
\hline & 46 & 34.3 & 88 & 65.7 & 134 & 14.2 & $(0.61-1.0)$ & \\
\hline \multirow[t]{2}{*}{ Girlfriend } & & & & & 941 & & 1.87 & $0.0000 *$ \\
\hline & 56 & 74.7 & 19 & 25.3 & 75 & 8.0 & $(1.6-2.19)$ & \\
\hline \multirow[t]{2}{*}{ Male friend } & & & & & 941 & & 1.29 & $0.0009 *$ \\
\hline & 225 & 48.0 & 244 & 52.0 & 469 & 49.8 & $(1.11-1.5)$ & \\
\hline \multirow[t]{2}{*}{ Female friend } & & & & & 941 & & 1.29 & $0.0343 *$ \\
\hline & 44 & 53.7 & 38 & 46.3 & 82 & 8.7 & $(1.04-1.6)$ & \\
\hline \multirow[t]{2}{*}{ No one } & & & & & 939 & & 0.69 & $0.0061 *$ \\
\hline & 35 & 30.7 & 79 & 69.3 & 114 & 12.1 & $(0.52-0.92)$ & \\
\hline
\end{tabular}

$\mathrm{SA}=$ sexually active, $\mathrm{NSA}=$ non-sexually active.

$\mathrm{RR}=$ risk ratio

$95 \% \mathrm{Cl}=95 \%$ confidence interval

$\mathrm{P}$ value for $\mathrm{M}-\mathrm{H} \chi^{2}$

* significant

ly, can prevent poor health and social outcomes, including unintended pregnancies and STD/AIDS, although the research does not demonstrate a relationship between family connectedness and delays in sexual debut (Huerta-Franco et al., 1996; ENJ OVEN, 1997; Resnick et al., 1997; Emmons et al., 1998).

Participating in sports (selected as one of the most favorite activities among students) was shown to be a protective factor against early sexual debut. Helping at home was also shown to be a protective factor, perhaps indicative of a connected relationship to the adolescent's family. However, other co-occurring activities, such as going to parties, seeing friends, watching pornographic videos and reading pornographic magazines, and use of tobacco, alcohol, and drugs were found to be associated with being sexually active (McLean \& Flanigan, 1993; Capaldi et al., 1996; ENJOVEN, 1997; Califano, 1998; Emmons et al., 1998). These risk behaviors, which have often been noted to co-occur, are cumulative and increase with age (Brener \& Collins, 1998).

Regarding information on sexuality, nearly one-half of students reported that they talked with their male friends, $20 \%$ with their fathers, and $5.9 \%$ with their teachers. These findings point to the value of peers and fathers in the transmission of information when there is a good level of interpersonal communication (Gonzalez et al., 1994; Huerta-Franco et al., 1996). In addition, talking about sexuality with peers of both sexes, as well as their girlfriends, was associated with sexual activity. This relationship may reflect increased peer pressure, lack of personal risk perception, and/or because the adolescent had al ready decided to engage in a sexual relationship (Moran \& Corley, 1991; Millan et al., 1995; Capaldi et al., 1996; Alexander \& Hickner, 1997). In contrast, speaking with their mothers or relying on themselves for information were found to be protective factors in delaying the onset of sexual activity. This may reflect a closer relationship with a parent who likely would discourage sexual activity and a personal quality of shyness that could also discourage sexual activity. However, the limited reliance on teachers does not bode well for the current state of trust with this potential source of support and information about such crucial topics. In order to assure the implementation of successful programs, it will be imperative to attract teachers who can establish a non-judgment and trusting relationship with their students.

Although the majority indicated that they had an "average" to "high" degree of knowledge regarding sexuality, clearly the level of accurate knowledge is relatively limited (11 correct answers out of 20 questions). While students who felt they had an average or high degree of knowledge tended to have sexual relations, the actual level of knowledge was not found to be associated with sexual activity. High self-ratings of knowledge, rather than their actual levels, were associated with sexual activity, and these findings are somewhat consistent with other studies who found a limited relationship between knowledge and sexual activity (ENJOVEN, 1997; Goldfarb, 1997; Ruusuvaara, 1997). 
Table 4

Profile of sexually active and non-sexually active male students

\begin{tabular}{|c|c|c|c|c|c|c|c|c|}
\hline \multirow[t]{2}{*}{ Variable } & \multicolumn{2}{|c|}{ SA } & \multicolumn{2}{|c|}{ NSA } & \multicolumn{2}{|c|}{ Total } & \multirow{2}{*}{$\begin{array}{l}\text { RR } \\
\text { (Cl) }\end{array}$} & \multirow[t]{2}{*}{$\mathrm{p}$} \\
\hline & $\mathrm{n}$ & $\%$ & $\mathrm{n}$ & $\%$ & $\mathrm{n}$ & $\%$ & & \\
\hline \multicolumn{9}{|l|}{ Knowledge } \\
\hline Self-ratings in knowledge & & & & & 931 & & 1.24 & $0.0299 *$ \\
\hline Average - great deal & 324 & 44.1 & 410 & 55.9 & 734 & 78.8 & $(1.01-1.52)$ & \\
\hline Little - nothing & 70 & 35.5 & 127 & 64.5 & 197 & 21.2 & & \\
\hline Actual level & & & & & 936 & & 0.89 & 0.1468 \\
\hline$\leq 9$ correct answers & 120 & 39.0 & 188 & 61.0 & 308 & 32.9 & $(0.75-1.05)$ & \\
\hline$\geq 10$ & 276 & 43.9 & 352 & 56.1 & 628 & 67.1 & & \\
\hline \multicolumn{9}{|l|}{ Attitudes } \\
\hline \multirow[t]{2}{*}{ Difficult to use a condom } & & & & & 905 & & 1.2 & $0.0255^{*}$ \\
\hline & 128 & 48.1 & 138 & 51.9 & 266 & 29.4 & $(1.03-1.4)$ & \\
\hline \multirow[t]{2}{*}{ Impossible to say no to having sex } & & & & & 911 & & 0.78 & $0.0017 *$ \\
\hline & 137 & 36.2 & 241 & 63.8 & 378 & 41.8 & $(0.66-0.91)$ & \\
\hline \multirow[t]{2}{*}{ Can control sexual desire } & & & & & 917 & & 0.81 & 0.0097 \\
\hline & 260 & 39.9 & 391 & 60.1 & 651 & 71.0 & $(0.7-0.95)$ & \\
\hline \multicolumn{9}{|l|}{ Hypothetical situations } \\
\hline \multirow[t]{2}{*}{ Acquire an STD } & & & & & 908 & & 1.28 & $0.0017^{*}$ \\
\hline & 179 & 48.5 & 190 & 51.5 & 369 & 40.6 & $(1.1-1.48)$ & \\
\hline \multirow[t]{2}{*}{ Get someone pregnant } & & & & & 915 & & 1.52 & $0.0000 *$ \\
\hline & 214 & 52.5 & 194 & 47.5 & 408 & 44.6 & $(1.31-1.77)$ & \\
\hline \multicolumn{9}{|l|}{ Sexual experience } \\
\hline \multirow[t]{2}{*}{ Ever had ejaculation } & & & & & 897 & & 2.94 & $0.0000 *$ \\
\hline & 336 & 53.2 & 296 & 46.8 & 632 & 70.5 & $(2.25-3.83)$ & \\
\hline \multirow[t]{2}{*}{ Ever had a girlfriend } & & & & & 926 & & 2.85 & $0.0000 *$ \\
\hline & 350 & 51.3 & 332 & 48.7 & 682 & 73.7 & $(2.16-3.76)$ & \\
\hline Number of girlfriends & & & & & 559 & & 1.84 & $0.0000 *$ \\
\hline$>2$ & 182 & 63.2 & 106 & 36.8 & 288 & 51.5 & $(1.53-2.22)$ & \\
\hline$\leq 2$ & 93 & 34.3 & 178 & 65.7 & 271 & 48.5 & & \\
\hline Reasons for having sex & & & & & 852 & & 1.35 & $0.0004 *$ \\
\hline Pleasure/fun & 134 & 49.4 & 137 & 50.6 & 271 & 31.8 & $(1.15-1.58)$ & \\
\hline Love/fear of loss partner & 213 & 36.7 & 368 & 63.3 & 581 & 68.2 & & \\
\hline \multicolumn{9}{|l|}{ Contraception } \\
\hline I would have anal sex & & & & & 826 & & 1.64 & $0.0000 *$ \\
\hline Yes & 161 & 60.5 & 105 & 39.5 & 266 & 32.2 & $(1.38-1.94)$ & \\
\hline No & 124 & 37.0 & 211 & 63.0 & 335 & 40.6 & 1.28 & 0.0463 \\
\hline Don't know & 65 & 28.9 & 160 & 71.7 & 225 & 27.2 & $(1.00-1.64)$ & \\
\hline
\end{tabular}

$\mathrm{SA}=$ sexually active, $\mathrm{NSA}=$ non-sexually active.

$\mathrm{RR}=$ risk ratio

$95 \% \mathrm{Cl}=95 \%$ confidence interval.

$\mathrm{p}$ value for $\mathrm{M}-\mathrm{H} \chi^{2}$.

* significant. 
The majority of participants had positive attitudes towards sexual activity and the use of a contraceptive if faced with an opportunity to engage in sexual relations. However, they also expressed ambivalent feelings regarding both sexual and contraceptive behavior. While stating that "it would be difficult to get accustomed to using a condom" and "it would be impossible to say no to having sexual relations", they also often expressed the opposite view: "I would protect myself when I have sexual relations" and "I could control my sexual desire". Thus, there are many conflicting or ambivalent attitudes and beliefs that influence sexual risk-taking behaviors that need to be considered in developing effective interventions (Hodges et al., 1992; Leland \& Barth, 1992; Huerta-Franco et al., 1996; ENJOVEN, 1997).

Although the majority of respondents indicated that they would be willing to use a condom if they wanted to prevent a pregnancy and others indicated that they would be willing to seek information in a family planning center before they became sexually active, bridging intentionally into action is still evasive. In part, this reflects a belief, held by $40 \%$ of the participants, that it is the female partner who must protect herself against pregnancy and STDs. Fully one-third of participants reported that they would have anal sex rather than use a condom (McGuire et al., 1992; Langille et al., 1994; Witwer, 1997).

Two-thirds of students reported that they had had their first ejaculation at 13 years of age. Biological development has been associated with earlier exposure to sexual activity and having gotten someone pregnant (Halpern et al., 1993). There is also an increased probability of acquiring an STD. Furthermore, many adolescents did not see themselves as vulnerable to negative consequences, based on the high percentages of adolescents who did not know or did not believe that it was possible for them to get an STD, become infected by HIV, or get someone pregnant. Similar findings have been observed among adolescents from other South American countries (Morris, 1988; Milan et al., 1995), as well as in the United States (Weisman, 1989; Resnick et al., 1997). These findings may in part relate to lack of risk perception among their peers, adolescent developmental issues pertaining to not understanding the consequences of their actions, and the fact that their risk behaviors have been reinforced by their positive short-term effects (e.g., pleasure or group approval of sexual activity), rather than more immediate negative consequences (e.g., a pregnancy scare) (Hunter \& Schaechner, 1992).
Table 5

Profile of sexually active adolescent males.

\begin{tabular}{lcc}
\hline Variable & Odds Ratio & $95 \% \mathrm{Cl}$ \\
\hline Ever repeated a grade & 1.94 & $1.38-2.74$ \\
Having had a girlfriend & 2.74 & $1.74-4.29$ \\
Talking about sex with girlfriend & 2.76 & $1.45-5.24$ \\
Having had first ejaculation & 4.5 & $2.84-7.12$ \\
Impossible to say no to having sex & 0.8 & $0.55-1.17$ \\
\hline
\end{tabular}

$\mathrm{Cl}=$ confidence interval.

Almost half of male students had had sex, with early age at sexual debut. These findings are consistent with data from several population-based surveys conducted in South America and the Caribbean, in which $21 \%$ to $63 \%$ of respondents had had premarital sexual experience, with a mean age of 15 years for males (Morris, 1988; CDC, 1992; Walrond et al., 1993; ENJOVEN, 1997).

These findings further reinforce the need for specifically targeting males when they are young and creating tailored, gender-specific prevention strategies aimed at modifying attitudes and risk behaviors. Such interventions have been found to be successful in modifying male behavior in other settings, resulting in an incremental use of condoms over time (Strunin \& Hingson, 1987; Hingson et al., 1990; Witwer, 1997). Such efforts may be especially challenging with these adolescents, because only onefourth of students expressed their willingness to use a condoms. Many participants gave multiple reasons for not using condoms, demonstrating the strong feelings that must be overcome to increase successful condom use among this population group. For example, the majority expressed the opinion that condoms decrease sexual pleasure (Hingson et al., 1990). Nevertheless, significant changes in condom use have been shown as they have become more widely accepted both for protection against STDs and HIV/ AIDS and for preventing unintended pregnancy (Kegeles et al., 1988; Pleck et al., 1993; Millan et al., 1995; Witwer, 1997).

Half of students believed that "many of their male friends have al ready had sex" and the majority believed that "few or none had used a condom". These perceptions are important to consider insofar as they place additional pressure on the male. They also have implications for developing interventions aimed at adolescents and hel ping to substantiate that the numbers of sexually active students may be far less and the 
use of contraceptives, particularly condoms, may be significantly higher than imagined by the youth (Lauritsen \& Swicegood, 1997).

Some of the perceptions regarding contraceptive use may in fact be accurate, as reflected in the low reported use of contraceptives in both the first and most recent acts of sexual intercourse. Despite the ambivalence regarding condom use, the majority of those who used contraceptives relied on this method for protection. This clearly points to the need to address efforts to expand and improve programs which lead adolescents to increase their sexual and contraceptive knowledge and establish the correct and consistent use of condoms among sexually active male adolescents.

This study has some design limitations, so that the findings can only be generalized to those male adolescent students with similar characteristics. In addition, we should consider the reliability of responses and potential under-reporting of sexual activity, given that data were collected in school settings. Finally, cau-

\section{Acknowledgments}

We wish to acknowledge the Ford Foundation's support for "Prevention of Sexual Risk Behaviors: A School-Based Sex Education Intervention Model" in Lima, Peru (Grant 950-0442). We also wish to thank Instituto de Estudios de Población (IEPO) collaborators Ludmila Reátegui, Olga Bardales, and Daniel Gallegos, who co-coordinated the school survey, and the students, parents, teachers, and school administrators that participated. tion is necessary in interpreting the "do not know" responses, which may reflect either not knowing what they would do under different circumstances or not knowing anything at all about the subject.

As documented by this profile of sexually active male adolescent students, interventions should be tailored to fit this import age/ gender group. We must also pursue strategies that reach males before they become sexually active. Strategies are needed to improve established education programs on sexuality and to make condoms and other contraceptive methods more readily available, as well as to reinforce active involvement by males in contraceptive decision-making. Perhaps most importantly, programs should focus on changing underlying, often contradictory and ambivalent, sexual attitudes and risk-taking behaviors, as well as preventing the co-occurrence of risk behaviors, such as reducing alcohol and drug use along with sexual behavior in order to promote the norm of responsible sexual activity.

\section{References}

ALEXANDER, E. \& HICKNER, J., 1997. First coitus for adolescents: Understanding why and when. Journal of American Board of Family Practice, 10:96103.

ALTHAUS, F., 1997. Children from disrupted families begin having sex and children at early age. International Family Planning Digest, 29:240-242.

ARAL, S., 1992. Sexual behavior as a risk factor for Sexually Transmitted Disease. In: Reproductive Tract Infections: Global Impact and Priorities for Women's Reproductive Health (A. Germain, K. Holmes, P. Piot \& J. Wasserheit, eds.), pp. 185-198, New York: Plenum Press.

BRENER, N. D. \& COLLINS, J. L., 1998. Co-occurrence of health-risk behaviors among adolescents in the United States. Journal of Adolescent Health, 22:209-213. 
BRUNHAM, R. \& EMBREE, J., 1992. Sexually Transmitted Diseases: Current and future dimensions of the problem in the Third World. In: Reproductive Tract Infections: Global Impact and Priorities for Women's Reproductive Health (A. Germain, K. Holmes, P. Piot \& J. Wasserheit, eds.), pp. 36-40, New York: Plenum Press.

CALIFANO, J., 1998. Editorial: Substance abuse and addiction - The need to know. American Journal of Public Health, 88:9-11.

CAPALDI, D. M.; CROSBY, L. \& STOOLMILLER, M., 1996. Predicting the timing of first sexual intercourse for at-risk adolescent males. Child Development, 67:344-359.

CDC (Centers for Disease Control and Prevention), 1992. Selected behavior that increase risk for HIV infection, other sexually transmitted disease and unintended pregnancy among high school students, United States, 1991. MMWR, 41:945-950.

DICLEM ENTE, R.; BOYER, C. \& MORALES, E., 1988. Minorities and AIDS: Knowledge, attitudes and misconceptions among black and latino adolescents. American Journal of Public Health, 78:5557.

DRYFOOS, J. G., 1988. Putting the Boys in the Picture. Santa Cruz: Network Publications.

EDWARDS, S. R., 1994. The role of men in contraceptive decision-making: Current knowledge and future implications. Family Planning Perspectives, 26:77-82.

EMMONS, K. M.; WECHSLER, H.; DOWDALL, G. \& ABRAHAM, M., 1998. Predictors of smoking among US College students. American Journal of Public Health, 88:104-107.

ENDES (Encuesta Demográfica y de Salud Familiar), 1992. Informe Final. Lima: Instituto Nacional de Estadística e Informática.

ENDES (Encuesta Demográfica y de Salud Familiar), 1997. Regulación dela Fecundidad, Conocimiento y Uso de Anticonceptivos. Informe Preliminar, 1997. Lima: Instituto Nacional de Estadística e Informática/Calverton: Programa de Encuestas de Demografía y Salud.

ENJOVEN (Encuesta Nacional de Jóvenes), 1997. Encuesta Nacional de Jóvenes. Informe Final. República Dominicana: Instituto de Estudios de Población y Desarrollo/Centers for Disease Control and Prevention.

GOLDFARB, A. F., 1997. Adolescent sexuality. Annals of the New York Academy of Sciences, 816:395-403.

GONZALEZ, C.; JIMENEZ, A.; GOMEZ, C.; BERENZON, S. \& MORA, J., 1994. El significado psicológico del concepto "Amiga" en adolescentes mexicanos: Una comparación por género. Acta Psiquiátrica y Psicológica de América Latina, 40:308313.

HALPERN, C. T.; UDRY, J. R.; CAMPBELL, B. \& SUCHINDRAN, C., 1993. Testosterone and pubertal development as predictors of sexual activity: A panel analysis of adolescent males. Psychosomatic Medicine, 55:436-447.

HINGSON, R.; STRUNIN, L. \& BERLIN, B., 1990. ACquired Inmunodeficiency Syndrome transmission: Changes in knowledge and behaviors among teenagers. Massachussetts Statewide Surveys 1986 to 1988. Pediatrics, 85:24-29.
HODGES, B. C.; LEAVY, M .; SWIFT, R. \& GOLD, R. S., 1992. Gender and ethnic differences in adolescents' attitudes toward condom use. Journal of School Health, 62:103-106.

HUERTA-FRANCO, R.; DIAZ-DE-LEON, J. \& MALACARA, J. M., 1996. Knowledge and attitudes toward sexuality in adolescents and their association with the family and other factors. Adolescence, 31:179-191.

HUNTER, J. \& SCHAECHNER, R., 1992. Adolescents and AIDS: Coping issues. In: Living and Dying with AIDS (P. Ahmed, ed.). New York: Plenum Press.

KEGELES, S.; ADLER, N. \& IRWIN, C., 1988. Sexually active adolescents and condoms: Changes over one year in knowledge, attitudes and use. American Journal of Public Health, 78:460-461.

KIERNAN, K. E. \& HOBCRAFT, J., 1997. Parental divorce during childhood: Age at first intercourse, partnership, and parenthood. Population Studies, 51:41-55.

LANDE, R., 1993. Las pérdidas infligidas por las ETS. Control de las enfermedades de transmisión sexual. Population Reports, 21:3-6.

LANGILLE, D.; BEAZLEY, R.; SHOVELLER, J. \&JOHNSTON, G., 1994. Prevalence of high risk sexual behaviour in adolescents attending school in a County in Nova Scotia. Canadian Journal of Public Health, 85:227-230.

LAURITSEN, J. L. \& SWICEGOOD, C. G., 1997. The consistency of self-reported initiation of sexual activity. Family Planning Perspectives, 29:215-221.

LELAND, N. L. \& BARTH, R. P., 1992. Gender differences in knowledge, intentions, and behaviors concerning pregnancy and Sexually Transmitted Disease prevention among adolescents. Journal of Adol escent Health, 13:589-599.

LOLI, A.; ARAMBURÚ, C. \& PAXM AN, J. M., 1987. Sexuality in Peru. International Family Planning Perspectives, Special Number:17-27.

MCCARTHY, J. \& MENKEN, J., 1989. Marriage, re-marriage, marital disruption and age at first birth. Family Planning Perspectives, 11:21-30.

MCGUIRE, E.; SHEGA, J.; NICHOLLS, G. \& DEESE, P., 1992. Sexual behavior, knowledge and attitudes about AIDS among college freshmen. American Journal of Preventive Medicine, 8:226-234.

MCLEAN, A. L. \& FLANIGAN, B. J., 1993. Transitionmarking behaviors of adolescent males at first intercourse. Adolescence, 28:579-595.

MILLAN, T.; VALENZUELA, S. \& VARGAS, N. A., 1995. Reproductive health in adolescent students: Knowledge, attitudes, and behavior in both sexes, in a community of Santiago. Revista Médica Chilena, 123:368-375.

MOORE, K. A. \& DRISCOLL, A., 1997. Partners, predators, peers, protectors. Males and teen pregnancy. In: Not Just for Girls: The Roles of Boys and Men and Boys in Teen Pregnancy Prevention (K. A. Moore, A. Driscoll \& T. Ooms, eds.), pp. 5-27, Washington, D.C.: The National Campaign to Prevent Teen Pregnancy.

MORAN, J. R. \& CORLEY, M. D., 1991. Sources of sexual information and sexual attitudes and behaviors of anglo and hispanic adolescent males. Adolescence, 26:857-582. 
MORRIS, L., 1988. Young adults in Latin America and Caribbean: Their sexual experience and contraceptive use. International Family Planning Perspectives, 14:153-158.

MORRIS, L., 1994. Sexual behavior of young adults in Latin America. In: Advances on Population: Psychosocial Perspectives (L. J. Severy, ed.), pp. 231252, London: Jessica Kinshley Publishers

PLECK, J. H.; SONENSTEIN, F. L. \& KU, L., 1993. Changes in adolescent males' use of and attitudes toward condoms, 1988-1991. Family Planning Perspectives, 25:106-110, 117.

RESNICK, M. D.; BEARMAN, P. S.; BLUM, R. W.; BAUMAN, K. E.; HARRIS, K. M.; JONES, J.; TABOR, J.; BEUHRING, T.; SIEVING, R. E.; SHEW, M.; IRELAND, M.; BEARINGER, L. H. \& UDRY, J. R., 1997. Protecting adolescents from harm: Findings from the National Longitudinal Study on Adolescent Health. JAMA, 278:823-832.

RUUSUVAARA, L., 1997. Adolescent sexuality: An educational and counseling challenge. Annals of the New York Academy of Sciences, 816:411-413.

STRUNIN, L. \& HINGSON, R., 1987. Acquired Inmunodeficiency Syndrome and adolescents: Knowledge, beliefs, attitudes and behaviors. Pediatrics, 79:825-828.
UPCHURCH, D. M. \& MCCARTHY, J., 1990. The timing of a first birth and highschool completion. American Sociological Review, 55:224-234.

WALROND, E.; JONES, F.; HOYOS, M.; SOUNDER, M.; ELLIS, H. \& ROACH, R., 1993. Conocimientos y actitudes de los adolescentes de barbados sobre el SIDA. Boletín dela Oficina Sanitaria Panamericana, 114:33-44.

WEISMAN, C., 1989. AIDS knowledge, perceived risk and prevention among adolescents clients of a family planing service. International Family Planning Perspectives, 21:213.

WITWER, M., 1997. Swiss program improves condom use, but levels of other HIV risk-related behavior are unchanged. Family Planning Perspectives, 29: 237-238.

WULF, D. \& SINGH, S., 1991. Sexual activity, union, and childbearing among adolescent women in the Americas. International Family Planning Perspectives, 17:137-144. 